\title{
Author Correction: Mechanisms governing the pioneering and redistribution capabilities of the non-classical pioneer PU.1
}

Julia Minderjahn, Andreas Schmidt, Andreas Fuchs (D), Rudolf Schill, Johanna Raithel, Magda Babina (i), Christian Schmidl (1), Claudia Gebhard, Sandra Schmidhofer, Karina Mendes, Anna Ratermann, Dagmar Glatz, Margit Nützel, Matthias Edinger, Petra Hoffmann, Rainer Spang, Gernot Längst (D), Axel Imhof (D) \& Michael Rehli (1D

Correction to: Nature Communications https://doi.org/10.1038/s41467-019-13960-2, published online 21 January 2020.

The original version of this Article contained an error in the spelling of the author Petra Hoffmann, which was incorrectly given as Petra Hoffman. This has been corrected in both the PDF and HTML versions of the Article.

Published online: 25 February 2020

\footnotetext{
(c) (i) Open Access This article is licensed under a Creative Commons Attribution 4.0 International License, which permits use, sharing, adaptation, distribution and reproduction in any medium or format, as long as you give appropriate credit to the original author(s) and the source, provide a link to the Creative Commons license, and indicate if changes were made. The images or other third party material in this article are included in the article's Creative Commons license, unless indicated otherwise in a credit line to the material. If material is not included in the article's Creative Commons license and your intended use is not permitted by statutory regulation or exceeds the permitted use, you will need to obtain permission directly from the copyright holder. To view a copy of this license, visit http://creativecommons.org/licenses/by/4.0/.
}

(C) The Author(s) 2020 